\title{
A New Procedure of the Tensile Fatigue Test for Dental Materials
}

\author{
Fumio NISHIMURA*, Hideo NAKAMURA*, Fumio WATARI*, \\ Itaru TANAKA* and Hidekazu TAKAHASHI** \\ *Department of Dental Technology I, Faculty of Dentistry, Tokyo Medical and Dental University, 1-5-45 \\ Yushima, Bunkyo-ku, Tokyo 113, Japan \\ ** Department of Fixed Prosthodontics, School of Dentistry, Showa University, \\ 2-1-1 Kitasenzoku, Ohta-ku, Tokyo 145, Japan
}

Received on July 13, 1992

Accepted on October 29, 1992

A new tensile fatigue test using a stainless steel screw was introduced. A transparent PMMA rod was selected as the test material. A hole was drilled and tapped into the rod; a screw was put into the rod with dental cement or without cementation. Three types of cyclic loads were applied to the test piece ; the number of times the load was applied when the initial crack was observed and when the final fracture occurred were recorded. Surface observation showed that actual fatigue fractures occurred in the test piece. The preferred applied load waveform was the cyclic haver-triangles load because of the small coefficient of variance. Fatigue strengths of test pieces with and without cementation were different. Cementation improved the fatigue properties, and the type of cement had an effect on the fatigue properties. Although the number of final fractures minus the number of initial cracks was the constant regardless of the type of cement used.

Key words : Fatigue test, S-N curve, Waveform effect

\section{INTRODUCTION}

The amount of chewing by a normal human being is estimated to be more than one million chews per year. The dental material used in the mouth must resist not only a single large force but also repeated small forces during mastication. The repeated stress sometimes results in fatigue fractures. Thus, mechanical properties of a dental material must be tested not only by a static method but also by a dynamic method. The fatigue property, by which life of the material is predicted and the structural design will be planned, is one of the typical properties revealed by the dynamic test method; this property is tested by tensile or torsional force ${ }^{1)}$. Due to the difficulty in preparation of the test piece, only a few studies have reported fatigue properties of dental materials, especially brittle materials, e. g., a dental cement $^{2-4)}$, a dental amalgam ${ }^{5-7)}$, a composite $\operatorname{resin}^{8-10)}$ and so on. We developed a new method for the tensile fatigue test using a stainless steel screw. In this study, we introduced the test procedures and evaluated a suitable test condition.

\section{MATERIALS AND METHODS}

A commercial transparent polymethylmethacrylate (PMMA) rod $(6 \mathrm{~mm}$ in diameter and $20 \mathrm{~mm}$ in length) was used as the test material. This rod was drilled and tapped for the preparation of a screwed hole; the diameter and the depth of the hole and the tapped pitch and height of the thread were $1.6 \mathrm{~mm}, 4.5 \mathrm{~mm}, 0.2 \mathrm{~mm}$ and $0.45 \mathrm{~mm}$, respectively. A stainless 
steel screw (SUS304) $)^{\sharp 1}$ corresponding to the screwed hole was inserted into the acrylic rod luted with either a zinc phosphate cement $(\mathrm{ZP}, \mathrm{P} / \mathrm{L}: 1.45 \mathrm{~g} / 0.5 \mathrm{ml})^{\sharp 2}$, a zinc oxide eugenol cement (ZOE, P/L : $1.0 \mathrm{~g} / 0.3 \mathrm{~g})^{\sharp 3}$, or without any cement (Fig. 1). All test pieces were stored on a bench in the laboratory; the fatigue test was performed 24 hours after preparation. The test piece was mounted in a digital servohydraulic testing machine ${ }^{\sharp 4}$ with a universal chuck and a holding jig (Fig. 2). In this study, a stress-controlled cyclic load was used.

A sinusoidal cyclic unipolar load (i. e., haver-sines cyclic load) of $2 \mathrm{~Hz}$ was employed to obtain the stress-number diagram of the test specimens without cementation. The number of times the load was applied when an initial visible fatigue crack was observed with a loupe of 5 magnification was recorded as $\mathrm{Nc}$; the number of times the load was applied when the test piece was fractured was recorded as Nf. The applied maximum tensile stress varied from $40 \mathrm{MPa}$ to $5 \mathrm{MPa}$; the applied minimum tensile stress was constantly $0.6 \mathrm{MPa}$.

To estimate the effect of waveforms of cyclic load on the test pieces without cementa-

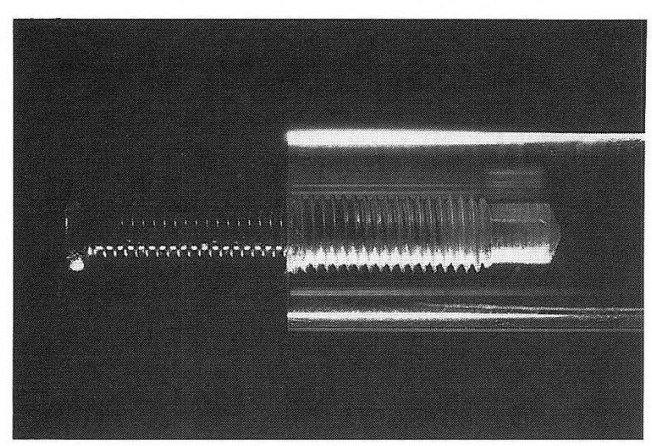

Fig. 1 Test piece of the acrylic specimen and the stainless steel screw.

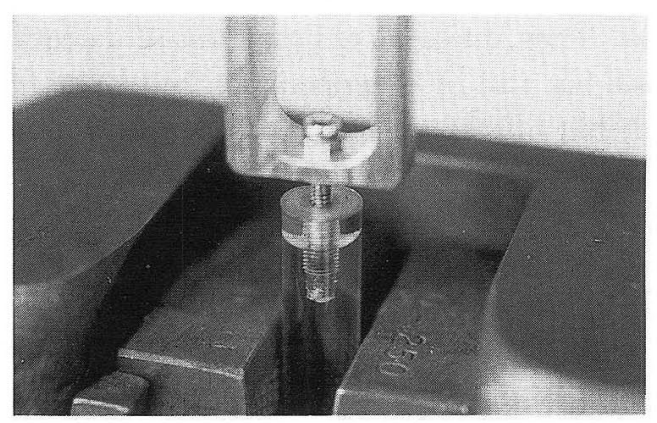

Fig. 2 Test piece set in the fatigue test machine.

\#1 Nitoh Seikoh, Tokyo, Japan

\#2 Elite 100, GC, Tokyo, Japan

\#3 Eugedyne, Showa Pharm., Tokyo, Japan

\#4 Model. 8500, Instron Corp., MA. USA 
tion and with ZP cementation, the haver-sines, haver-squares and haver-triangles cyclic loads (maximum tensile stress : $18.8 \mathrm{MPa}$, minimum tensile stress : $1.3 \mathrm{MPa}$ ) of $1 \mathrm{~Hz}$ were selected (Fig. 3). A haver-triangles cyclic load of $1 \mathrm{~Hz}$ was also applied to the test piece with $\mathrm{ZOE}$ cementation for comparison of the various luting materials.

The static tensile strengths of test pieces with ZP cementation and without any cementation were tested with a $490 \mathrm{~N} / \mathrm{min}$ load speed.

The fractured surfaces of the test pieces were observed with a microscope $\$$.

All test procedures were done in an ambient laboratory atmosphere $\left(23 \pm 2^{\circ} \mathrm{C}\right.$ temperature and $(50 \pm 10) \%$ relative humidity).

\section{RESULTS}

Figure 4 shows a typical situation of this fatigue test when a crack of the test piece was propagated. The initial crack growth was always observed at the end of the fixed screw ; the

Cyclic unipolar wavoform

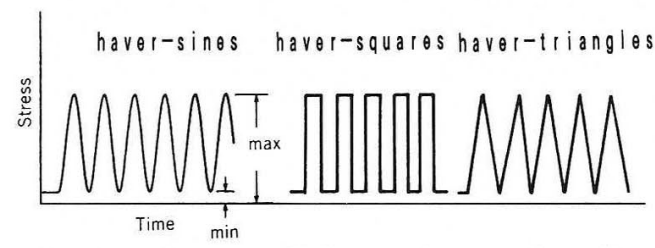

Fig. 3 Three applied waveforms of cyclic load.

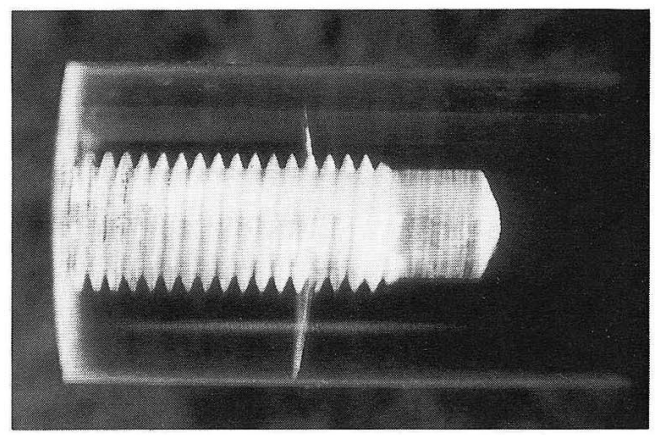

Fig. 4 The initial crack was observed from the terminal edge of the stainless steel screw and the crack propagated laterally.

\$ Versamat, Union Kohgaku, Tokyo, Japan 
crack developed laterally with an increase in the number of times the load was applied. The obvious fatigue striations and the final fracture surface were observed by a microscope (Fig. 5).

The stress-number diagram is shown in Fig. 6. The applied stress represents the applied maximum load divided by the test specimen's cross-sectional area which was the result of subtracting the tapped hole's cross-sectional area from the PMMA rod's cross-sectional area. Within the range of the applied stress used in this study, there was no horizontal line at high cycles.

The effects of the waveforms and the luting materials on the $\mathrm{Nc}$ and the $\mathrm{Nf}$ are summarized in Table 1. Regarding the waveform, there was a significant difference among the three waveform's means of their Ncs and Nfs with ZP cementation by the one-way analysis of variance (ANOVA); that of the haver-triangles cyclic load was significantly larger than the others by the Scheffe multiple comparison test $(p<0.01)($ Fig. 7$)$; there was

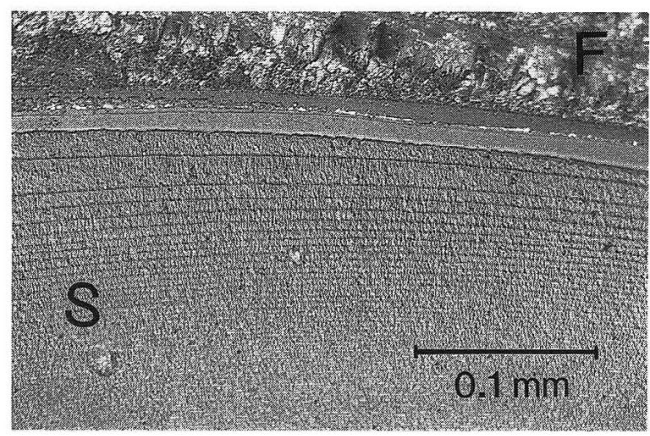

Fig. 5 Fracture surface of tested specimen applied with a $2 \mathrm{~Hz}$ cyclic load : obvious fatigue striation (S) and final fracture surface $(\mathrm{F})$.

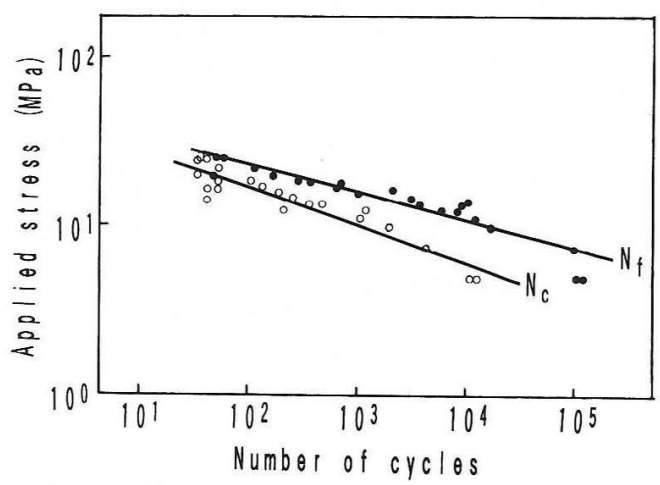

Fig. 6 S N diagram : applied maximum load varied from $40 \mathrm{MPa}$ to $5 \mathrm{MPa}$, minimum load was $0.6 \mathrm{MPa}$. 
Table 1 Summary of effects of applied stress waveform and cement materials on fatigue strength ; Nc: number of applied load when an initial crack was observed, Nf: number of applied load when the final fracture occurred. $(-)$ : without cementation; $(\mathrm{ZOE})$ : cementation with the zinc oxide eugenol cement; $(Z P)$ : cementation with the zinc phosphate cement

\begin{tabular}{lrccccc}
\hline \hline \multirow{2}{*}{ waveform } & \multicolumn{2}{c}{$(-)$} & \multicolumn{2}{c}{ ZOE } & \multicolumn{2}{c}{ ZP } \\
\cline { 2 - 7 } & \multicolumn{1}{c}{$\mathrm{Nc}$} & $\mathrm{Nf}$ & $\mathrm{Nc}$ & $\mathrm{Nf}$ & $\mathrm{Nc}$ & $\mathrm{Nf}$ \\
\hline Haver-sine & $67 \pm 29$ & $440 \pm 210$ & & & $390 \pm 70$ & $1125 \pm 130$ \\
Haver-square & $80 \pm 79$ & $506 \pm 315$ & & & $260 \pm 82$ & $2425 \pm 746$ \\
Haver-triangle & $147 \pm 50$ & $1020 \pm 88$ & $327 \pm 64$ & $4339 \pm 690$ & $1923 \pm 433$ & $5911 \pm 375$ \\
\hline
\end{tabular}

$\mathrm{n}=3$, mean $+\mathrm{S}$. D.

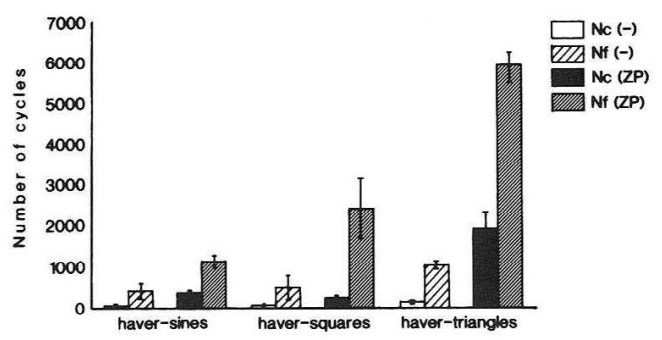

Fig. 7 Effect of waveform on the Nc and the $\mathrm{Nf}$; the Nc means the number of times the load was applied when an initial crack was observed; the $\mathrm{Nf}$ means the number of times the load was applied when the final fracture occurred. (-): without cementation; $(\mathrm{ZP})$ : with the cementation using zinc phosphate cement.

no significant difference between the mean of the $\mathrm{Nc}$ or the $\mathrm{Nf}$ obtained from the haver-sines load and the $\mathrm{Nc}$ or the $\mathrm{Nf}$ from the haver-squares load, respectively. In addition, there was no significant difference among the three waveform's means of the Nc without cementation by the one-way ANOVA; there was a significant difference among those of the Nf without cementation. The coefficient of variances (CV) of the $\mathrm{Nc}$ without cementation using the cyclic haver-sines, haver-squares and haver-triangles loads were $43.3 \%, 99.2 \%$ and $34.3 \%$, respectively ; the $\mathrm{CVS}$ with $\mathrm{ZP}$ cementation were $18.0 \%, 31.5 \%$ and $22.5 \%$, respectively. The $\mathrm{CVs}$ of the $\mathrm{Nf}$ without cementation using the cyclic haver-sines, haver-squares and havertriangles loads were $47.7 \%, 62.2 \%$ and $8.5 \%$, respectively ; the CVs with $\mathrm{ZP}$ were $11.5 \%, 30$. $8 \%$ and $6.3 \%$, respectively.

Compared with the luting materials which applied the haver-triangles cyclic load, the $\mathrm{Ncs}$ or the Nfs with cementation were significantly larger than the Ncs or the Nfs without cementation, respectively (Fig. 8). With respect to ZOE cementation, the Nf was approximately four times larger than the Nf without cementation; however, the Nc was approximately twice as large than the Nc without cementation. Regarding ZP cementation, the Nf 
was approximately six times larger than the Nf without cementation; however, the Nc was thirteen times larger.

The mean and standard deviations of the static tensile strength without cementation were $15.1 \mathrm{MPa}$ and $2.4 \mathrm{MPa}$, respectively; those with $\mathrm{ZP}$ cementation were $26.7 \mathrm{MPa}$ and $2.6 \mathrm{MPa}$, respectively. The tensile strength with $\mathrm{ZP}$ cementation was 1.5 times larger than that without cementation. The fracture surface obtained from the static tensile test was very rough compared with the fracture surface obtained from the fatigue test (Fig. 9).

\section{DISCUSSION}

In the conventional tensile fatigue test, the crack propagates from the surface to the inside $^{1)}$; however, in this new test, the crack propagates from the internal hole to the outside. As a result, it is rather difficult ot compare the results of the conventional test with those of

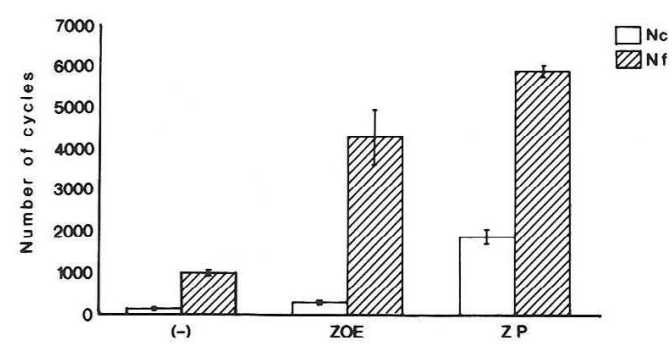

Fig. 8 Effect of luting materials; $(-)$ : without cementation; $(\mathrm{ZOE})$ : cementation with zinc oxide eugenol cement ; $(\mathrm{ZP})$ : cementation with zinc phosphate cement.

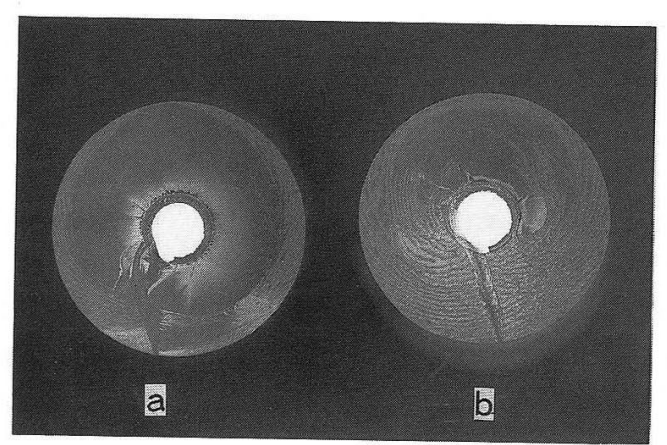

Fig. 9 Fracture surface.

(a) fracture surface of an applied cyclic load of the maximum of $10 \mathrm{MPa}$ haver-sines

(b) fracture surface resulting from the static tensile strength test 
this method. By this method, the condition of the outer surface of the test specimen will not affect the result. Preparation of the test piece for this method was not difficult, and it was also possible to embed a screw directly into the test material.

This new tensile fatigue test is a precrack fatigue test because the terminal edge of the screw acts as a precrack. As a result, the crack propagation of each tested specimen was initiated from the terminal edge of the screw. On the other hand, with the photoelastic test, some researchers ${ }^{11-13)}$ reported that an applied stress caused stress concentration around the terminal edge of the screw post. Our observation of the initial crack position agreed with a previously reported position of stress concentration.

A PMMA rod was used as the test material because of its easy machinability and excellent transparency; as a result, a uniform shape of the screw hole could be prepared. The SUS 304 stainless steel used in this study is very popular for dental application, being employed for example, in screw posts for core build-up. The initial crack growth could be visually detected without a special apparatus. Observation of the fractured surfaces revealed an actual fatigue fracture such as that shown in Fig. 4.

Fatigue strength is little affected by a frequency in the low frequency range ${ }^{14)}$, and our preliminary experiment showed no difference between the fatigue properties when $1 \mathrm{~Hz}$ or $2 \mathrm{~Hz}$ cyclic loads were applied ; therefore, the $1 \mathrm{~Hz}$ cyclic load was employed for the experiment of waveform effect because of the easy detection of the initial crack ; the $2 \mathrm{~Hz}$ cyclic load was employed for the $\mathrm{S}-\mathrm{N}$ diagram because of the reduction in experimental time.

The shape of the S-N diagram obtained from this study was similar to that of previous reports on the PMMA ${ }^{15,16)}$. The following equation was calculated with the obtained $\mathrm{S}-\mathrm{N}$ diagram ${ }^{177}$.

$$
\begin{aligned}
& \log \mathrm{S}=1.71-0.17 \log \mathrm{Nf} \\
& \log \mathrm{S}=1.68-0.22 \log \mathrm{Nc}
\end{aligned}
$$

The $\mathrm{S}$ in the equation is the maximum applied stress. As a result, the fatigue parameters of the $\mathrm{Nc}$ and the $\mathrm{Nf}$ were 4.5 and 6.0, respectively. This indicated amplitude of the maximum applied stress effected the final fracture more strongly than the crack initiation. Moreover, a ten-percent decrease of the applied stress caused a 1.6 times larger the number of times the cyclic load was applied when an initial crack was observed; however this decrease caused a 2.0 times larger the number of times the cyclic load was applied when the final fracture had occurred.

The waveform is one of the influential factors of the fatigue properties. According to the obtained figures, the mean of the $\mathrm{Nc}$ and the $\mathrm{Nf}$ of the cyclic haver-triangles load was the largest ; in addition, the coefficient of variance $(\mathrm{CV})$ of the $\mathrm{Nf}$ of the cyclic haver-triangles load was the smallest. In terms of the structural mechanism of the test machine, a cyclic haver-sines load is usually selected for applied fatigue stress. However, the best applied stress was considered to be the cyclic haver-triangles load because of the small coefficient of variance.

The applied load of the tested specimen without cementation acted mainly as tensile stress ; however, the applied load also acted as torsional stress because of a small amount of play between the tapped hole and the screw. As a result, the $\mathrm{Nc}$ and the $\mathrm{Nf}$ of the test pieces without cementation were significantly small. For the same reason, the static tensile strength 
without cementation was weaker than that with $Z \mathrm{P}$ cementation. These results suggested that the screw cemented or directly embedded into the test material was more favorable because the test piece was then free from torsional stress. With respect to the luted test specimen, applied force initially destroyed the cement layer between the acrylic specimen and the screw; applied force secondly destroyed the acrylic specimen. The mechanical properties, such as compressive strength and diametral strength, of the zinc oxide eugenol cement were weaker than those of the zinc phosphate cement ${ }^{18)}$. The fatigue strength of the zinc oxide eugenol cement is considered to be weaker than that of the zinc phosphate one. Consequently, the $\mathrm{Nc}$ with $\mathrm{ZOE}$ cementation was smaller than that with ZP cementation. After the crack was initiated, it propagated regardless of the type of cement used. The remainder of the $\mathrm{Nc}$ from the $\mathrm{Nf}$ with $\mathrm{ZOE}$ cementation was, therefore, almost equal to that with ZP.

As seen from the obtained results, this new tensile fatigue test caused a fatigue fracture. With this test, it is possible to distinguish differences among not only the tested materials but also the cement material luting the screw. This testing method is applicable to dental materials, especially brittle materials, e. g., dental cement, dental amalgam, dental gallium alloy, composite resin, dentin of the tooth and so on.

\section{CONCLUSION}

A new tensile fatigue test method with a stainless steel screw was introduced. By this method, actual fatigue fractures occurred in the acrylic test specimen. The number of times the cyclic load was applied the crack was initiated and when the final fracture occurred varied with the applied waveform. The more favorable waveform of applied load was considered to be the cyclic haver-triangles load. Luting of the screw with a cement strengthened the fatigue properties; therefore, it was considered better for the screw to be cemented or be directly embedded into the tested material. The type of cement had an effect on the fatigue properties; however, the difference of numbers of times of applied load between the initiate crack and the final fracture with cementation using zinc oxide eugenol cement and that using the zinc phosphate cement was nearly the same.

\section{ACKNOWLEDGEMENT}

This study was supported in part by a Grant-in-Aid for Scientific Research 1989 (A01440079) from the Ministry of Education, Science and Culture, Japan.

\section{REFERENCES}

1) Moore, H. F.: Fatigue tests, edited by Lyman, T., Metals Handbook, 1948ed., The American Society for Metals, Cleveland, 1948, pp. 118-124.

2) Okabe, T., Nakajima, H., Marker, V., Hashimoto, K., Hanaoka, K., Miyakuni, S., Teranaka, T. and Iwamoto, T.: Strength and fracture characteristics of dental glass ionomers under static or dynamic loading, International Symposium for Testing and Failure Analysis 1989: 447-452, 1989.

3) Nakajima, H. and Okabe, T.: Fatigue resistance and fracture mode of dental luting cements, Interna- 
tional Symposium for Testing and Failure Analysis 1989: 453-458, 1989.

4) Okazaki, K. and Nishimura, F. : Fatigue of a dental zinc phosphate cement, $J$ J Dent Mat 9 (6) : 871 -877, 1990. (in Japanese)

5) Wilkinson, E. G. and Haack, D. C. : A study of the fatigue characteristics of silver amalgam, $J$ Dent Res 37 (1): 136-143, 1958.

6) Sutow, E. J., Jones, D. W., Hall, G. C. and Milne, E. L. : The response of dental amalgams to dynamic loading, J Dent Res 64 (1) : 62-66, 1985.

7) Zardiacs, L. D. and Bayne, S. C.: Fatigue characterization of nine dental amalgams, Biomaterials 6 : 49-54, 1985.

8) Draughn, R. A. : Compressive fatigue limits of composite restorative materials, J Dent Res 58 (3) : 1093-1096, 1979.

9) Drummond, J. L. : Cyclic fatigue of composite restorative materials, J Oral Rehabil 16 (5): 509-520, 1989.

10) Horie, K., Nakajima, A. and Hosoda, H.: Durability of posterior restorative composite resins 1) The effect of repeated stress on composites, $J$ J Dent Mat 6 (2) : 228-235, 1987. (in Japanese)

11) Henry, P. L. : Photoelastic analysis of post core restorations, Aust Dent J 22 (3) : 157-159, 1977.

12) Standlee, J. P., Caputo, A. A., Collard, E. W. and Pollack, M. H.: Analysis of stress distribution by endodontic posts, Oral Surg 33 (6) : 953-960, 1972.

13) Aoyama. S., Takahagi. S., Kikkawa, H. and Hanamura, N.: Photoelastic studies on influences of various types of dowel on dental roots and improvement of experimental condition concerning the simulation of the periodontal membrane, Turumi Shigaku 8 (3): 319-327, 1982. (in Japanese)

14) The ASM Committee on Analysis of Fatigue Failures : Fatigue failures, edited by Boyer, H. E., Metals Handbook, 10, 8th ed., American Society for Metals, Metals Park. 1975, pp. 95-125.

15) Miyairi, H., Muramatsu, A., and Saitoh, N. : Influence of surface finishing and polymerization method on the fatigue strength of the dental plastics materials, Reports of Institutes for Medical \& Dental Engineering 5: 49-56, 1971. (in Japanese)

16) Fujii, K.: Fatigue properties of acrylic denture base resins, Dent Mater J 8 (2) : 243-259, 1989.

17) Wiederhorn, S. M. and Bolz, L. H. : Stress corrosin and static fatigue of glass, J Am Ceram Soc 53: 543-548, 1970.

18) O'Brien, W. J. and Ryge, G. : An outline of dental materials and their selection, W. B. Saunders Co., Philadelphia, 1978, pp. 396-413. 


\title{
本号掲載論文の和文抄録
}

\author{
$\mathrm{Nd}_{2} \mathrm{Fe}_{14} \mathrm{~B}$ 磁石および $\mathrm{SmCo}_{5}$ 磁石の腐食挙動 \\ 木次朝日*, 奥野 攻**, 中野 毅**, 浜中人士**, 黒田敬之* \\ *東京医科歯科大学歯科矯正学第二講座 \\ **東京医科歯科大学医用器材研究所金属部門
}

小型で強力な希土類系磁石は, 歯科補綴や矯正の装置 に用いられるようになってきた。このような応用を考え る上で希土類系磁石の口腔内環境下で吸引力の変化と腐 食について明らかにしておく必要がある。そこで $\mathrm{Nd}_{2}$ $\mathrm{Fe}_{14} \mathrm{~B}$ 磁石および $\mathrm{SmCo}_{5}$ 磁石を $37^{\circ} \mathrm{C}$ の $1 \%$ 塩化ナトリ ウム水溶液， $1 \%$ 乳酸水溶液, $0.05 \%$ 塩酸水溶液, $0.1 \%$ 硫化ナトリウム水溶液, 人工唾液に浸漬させ, 吸引力の 経時的変化, イオン溶出, 重量変化, アノード分極特性
を調べた、またステンレス鋼に磁石を入れレーザー溶接 により密封された磁性アタッチメントの耐食性を調べ た，密封されていない希土類系磁石の耐食性は不良であ った。特に $1 \%$ 乳酸水溶液中では, 激しく腐食され, 吸 引力も低下し溶出イオン量も多かった. 磁性アタッチメ ントの耐食性は良好であり,レーザー溶接を行ったステ ンレス鋼のカプセルは防錆効果があると考えられた。

\section{in vivo および in vitroにおけるリン酸八カルシウムの相変態}

\author{
伴 清治*, 神出敏影**, 長谷川 二郎* \\ *愛知学院大学歯学部歯科理工学講座 \\ **愛知学院大学歯学部口腔外科学第 2 講座
}

リン酸八カルシウム $\left[\mathrm{Ca}_{8} \mathrm{H}_{2}\left(\mathrm{PO}_{4}\right)_{6} \cdot 5 \mathrm{H}_{2} \mathrm{O}\right.$, 以下 $\mathrm{OCP}$ と略す]を $\mathrm{ddY}$ 系雄性マウスの両大腿部筋膜上に 3 週間 インプラントした. また, $\mathrm{OCP}$ 粉末を $37^{\circ} \mathrm{C}$ に保持した人 工体液および $1 \% \mathrm{NaCl}$ 溶液中に, 1 日, 1 週間, 3 週間 浸漬した。所定期間経過後, 試料は走查型電子顕微鏡, $\mathrm{X}$ 線回折，赤外分光分析により状態分析した．X線回折 の結果より，マウスに 3 週問インプラントした OCP は
すべて結晶性の低いアパタイトに転化していた。また， $1 \% \mathrm{NaCl}$ 溶液中に浸漬したものではアパタイトに転化 していた. 赤外分光分析結果より, これらのアパタイト には炭酸が含有されていた。一方, 人工体液中に浸漬し たものでは OCP はほとんど変化しなかった.これは, 人 工体液中の $\mathrm{Mg}$ イオンが $\mathrm{OCP}$ からアパタイトへの相変 態を遅延しているためと考えられる.

歯科材料引張疲労試験の新しい方法

西村文夫*, 中村英雄*, 亘理文夫*, 田中 至*, 高橋英和 ${ }^{* *}$

*東京医科歯科大学歯学部第一歯科理工学教室

**昭和大学茵学部第一歯科補綴学教室

ステンレス鋼製スクリューを測定試料に埋め込み，ス クリューと測定試料に繰り返し引張力を与える引張疲労
試験を考案した. 試験試料として PMMA 棒を選び,こ れにネジきりをし，スクリューを歯科用セメントで合着 
した試料と合着しない試料を製作した。負荷波形として サイン波, 矩形波, 三角波について検討した.PMMA 試 料を用いたため, 亀裂の発生が観察でき, 亀裂発生まて の繰り返し応力回数と, 試料の破断までの回数を記録し た．破断面を観察したところ，破壊疲労を示す表面性状 が観察された．負荷波形としては，測定值の変動係数が
小さい三角波形の負荷が望ましいと考えられた，疲労強 度はセメント合着により改善され，セメントの種類によ りその程度は異なった。しかし, 亀裂発生から破壊まて に与えられた繰り返し応力の回数はセメントの種類の影 響を受けなかった。

歯科修復物の辺縁封鎖性の新しい評価法

原嶋郁郎, 鵜澤 崇, 平澤 忠

鶴見大学歯学部歯科理工学教室

辺縁封鎖性評価のための新しい試験装置を開発した. この試験装置は熱サイクル負荷のための流路と漏洩検出 のための流路からなっており, 両流路は被験修復歯で隔 絶される、熱サイクル負荷系にはトレーサーとして使用 したローダミン B の冷熱水溶液を循環させておき， 6 つ の電磁弁の開閉で試験片に熱サイクルを与えられる。試 験片に熱サイクルを与えながら, 検出系を循環する蒸留
水中に漏洩してくるトレーサー量を定期的に分光光度計 で測定した．銀合金インレー修復，アマルガムあるいは グラスアイオノマー充填修復について漏洩デー夕を実験 式で解析したところ, 漏洩挙動をかなりよく説明でき, 熱サイクルに対する完全封鎖保持期間として辺縁封鎖性 を推定評価できた。

\section{$\mathrm{Ni}$ - Ti 合金鋳造体の機械的性質に及ぼす組成および純度の影響 米山隆之, 土居 寿, 浜中人士 東京医科菌科大学医用器材研究所金属材料部門}

$\mathrm{Ni}-\mathrm{Ti}$ 合金鋳造体の機械的性質および変態点に及ほ す組成およびチタンの純度の影響について,引張試験お よび示差走查熱量測定により検討した. 鋳造用インゴッ トの組成は, チタンの原子パーセントで 49.0 から 49.2 \%とし, 比較的純度の高い 3 種類のチタンを材料として 使用した.

その結果, Ni-49.0 Ti はやや脆い性質を示し, $\mathrm{Ni}$ -
$49.2 \mathrm{Ti}$ は低い見かけの耐力および高い伸びを示した， 残留ひずみは, チタンの組成が高くなるほど増加した。 また，チタンの純度のわずかな低下が, $\mathrm{Ni}-\mathrm{Ti}$ 合金の機 械的性質および変態点に影響を及ぼした。すなわち，変 態点が下がることにより, 見かけの耐力が高くなり, 残 留ひずみが小さくなり, 伸びが減少した.

フィラー含有量の異なるコンポジットレジンの水中浸漬下における圧縮クリープと回復 平野 進, 平澤 忠

鶴見大学歯学部歯科理工学教室

フィラー含有量の異なるコンポジットレジンを作製

し, その圧縮クリープと回復について水中浸漬下で研究
した. 500 時間後のコンポジットレジンのクリープひず みはコンポジットレジン中のフィラー含有量の増加にと 